\title{
Does prolonged cycling of moderate intensity affect immune cell function?
}

\author{
J Scharhag, T Meyer, H H W Gabriel, B Schlick, O Faude, W Kindermann
}

Br J Sports Med 2005;39:171-177. doi: 10.1136/bjsm.2004.013060

See end of article for authors' affiliations

.....................

Correspondence to: Dr Jürgen Scharhag, Institute of Sports and Preventive Medicine, University of Saarland, Campus, Building 39.1 66123 Saarbrücken, Germany; i.scharhag@mx. uni-saarland.de

Accepted 15 June 2004
Background: Prolonged exercise may induce temporary immunosuppression with a presumed increased susceptibility for infection. However, there are only few data on immune cell function after prolonged cycling at moderate intensities typical for road cycling training sessions.

Methods: The present study examined the influence on immune cell function of $4 \mathrm{~h}$ of cycling at a constant intensity of $70 \%$ of the individual anaerobic threshold. Interleukin-6 (IL-6) and C-reactive protein (CRP), leukocyte and lymphocyte populations, activities of natural killer (NK), neutrophils, and monocytes were examined before and after exercise, and also on a control day without exercise.

Results: Cycling for $4 \mathrm{~h}$ induced a moderate acute phase response with increases in IL-6 from 1.0 (SD 0.5) before to $9.6(5.6) \mathrm{pg} / \mathrm{ml} 1 \mathrm{~h}$ after exercise and CRP from 0.5 (SD 0.4) before to 1.8 (1.3) mg/l 1 day after exercise. Although absolute numbers of circulating NK cells, monocytes, and neutrophils increased during exercise, on a per cell basis NK cell activity, neutrophil and monocyte phagocytosis, and monocyte oxidative burst did not significantly change after exercise. However, a minor effect over time for neutrophil oxidative burst was noted, tending to decrease after exercise.

Conclusions: Prolonged cycling at moderate intensities does not seem to seriously alter the function of cells of the first line of defence. Therefore, the influence of a single typical road cycling training session on the immune system is only moderate and appears to be safe from an immunological point of view.
$\mathrm{T}$ raining and competition sessions in road cycling usually last several hours, and it is well established that prolonged exercise may induce a temporary immunosuppression termed the "open window" with a presumed increased susceptibility for infection. ${ }^{12}$ However, relatively few data are available on immune cell function after prolonged cycling at moderate intensities typical for road cycling training sessions, as cyclists usually spend about $80 \%$ of their training time below $65 \%$ maximal oxygen uptake $\left(\mathrm{Vo}_{2 \max }\right){ }^{3}$ Therefore, it was the aim of the present study to examine the influence of a standardised prolonged cycling session at moderate intensity on the function of immune cells which represent the so called "first line of defence".

It was hypothesised that cycling for $4 \mathrm{~h}$ at a constant intensity of $70 \%$ of the individual anaerobic threshold (IAT) ${ }^{4}$ would initiate an acute phase response, characterised by an increase in interleukin-6 (IL-6) and C-reactive protein (CRP), and would weaken the activity of natural killer cells (NK cells), neutrophils, and monocytes (phagocytosis and oxidative burst).

\section{METHODS}

\section{Subjects}

Twelve male competitive athletes (nine road cyclists, three triathletes; age 26 (SD 7) years, height 179 (5) cm, weight 71 (5) $\mathrm{kg}$, body fat $11.6 \%$ (3.8\%), heart volume 13.9 (1.6) ml/ $\mathrm{kg}$ ), who had been cycling for 6.5 (3.3) years and had spent 11 (3) h per week road training during the last season, were recruited for the study after giving their written informed consent. In addition to a physical examination, routine blood parameters were determined in each participant to exclude acute or chronic inflammatory diseases. An ECG at rest and during cycle ergometry as well as an echocardiography were performed to exclude cardiovascular abnormalities (ergometric data: maximal power output 365 (SD 35) W, maximal heart rate 191 (12) beats/min, maximal oxygen uptake 66
(6) $\mathrm{ml} / \mathrm{min} / \mathrm{kg}$, power output at the IAT 261 (32) $\mathrm{W}$ and 3.7 (0.5) W/kg, respectively).

\section{General design}

After an incremental stage test to determine the IAT, a constant load trial and an examination on a control day without exercise were performed in randomised order.

\section{Cycle ergometry}

To determine the IAT by the method of Stegmann et $a l,{ }^{4}$ an incremental multi-stage cycle ergometric test was started at a workload of $100 \mathrm{~W}$ and increased by $50 \mathrm{~W}$ every 3 min until exhaustion. Blood samples were taken from the hyperaemised earlobe at the end of each stage and 1, 3, 5, and 10 min after cessation of exercise to determine lactate concentrations (Super GL, Greiner Biochemica, Flacht, Germany). In addition, $\mathrm{Vo}_{2 \max }$ was measured by direct mixing chamber spirometry (Cortex MetaMax I, Leipzig, Germany).

\section{Constant load trial and control day}

The constant load trial of $4 \mathrm{~h}$ duration at an intensity of $70 \%$ IAT given in Watts was carried out on a $400 \mathrm{~m}$ track. Heart rate (Polar, Kempele, Finland) and oxygen consumption (Cortex MetaMax I) were recorded continuously. Subjects used their own bicycles which were equipped with an SRM powermeter (Schoberer, Jülich, Germany) to monitor workload. Blood samples from the hyperaemised earlobe to determine lactate concentrations were taken at rest and at the end of cycling after $4 \mathrm{~h}$. Fluid intake was permitted every 30 min and registered exactly; only mineral water with no carbohydrates or energy content was supplied. The tests took

Abbreviations: $A U$, arbitrary unit; CRP, C-reactive protein; $F M L P$, formylised-1-methionyl-1-leucyl-1-phenylalanin; IAT, individual anaerobic threshold; IL-2, interleukin-2; IL-6, interleukin-6; NK cells, natural killer cells; NKCA, NK cell cytotoxic activity 
place during the summer season between April and October Each participant started the trial at 9 am.

In addition, on a separate control day without any exercise an identical blood sampling schedule was performed on the same subjects to monitor the circadian rhythms of the determined parameters. Participants were told to take the same breakfast on the exercise and the control day at about 7 am. Strenuous exercise was forbidden on the days before the tests.

\section{Immunological parameters}

Blood samples were collected from an antecubital vein into tubes containing $\mathrm{K}_{3}$ EDTA $(2.7 \mathrm{ml})$ and lithium heparin $(7.5 \mathrm{ml})$ while subjects were in a supine position. Samples were obtained before (before), immediately after cessation of exercise (end), and 1,2 , and $19 \mathrm{~h}$ after exercise ( $1 \mathrm{~h}$ post, $2 \mathrm{~h}$ post, and 1 day post, respectively) for analysis of haematological parameters (whole blood cell counts, haemoglobin, haematocrit) using a cell counter (Sysmex K-1000, Sysmex, Langenfeld, Germany). Leukocyte and lymphocyte subpopulations were determined by flow cytometry (FACSScan, Becton Dickinson, Heidelberg, Germany) at the following time points: before, end, $1 \mathrm{~h}$ post, $2 \mathrm{~h}$ post, and $\mathrm{l}$ day post. NK cells were defined as $\mathrm{CD}^{-} \mathrm{CD}^{-} 6^{+} \mathrm{CD} 56^{+}$lymphocytes, and CD94 and CD158a receptors were determined on $\mathrm{CD}^{-}{ }^{-} \mathrm{CD} 6^{+}$ lymphocytes.

The activity of NK cells, neutrophils, and monocytes was also determined by flow cytometry. The NK cell cytotoxic activity (NKCA) was measured before and immediately after exercise. Neutrophil and monocyte phagocytic activity as well as their formylised-1-methionyl-1-leucyl-1-phenylalanin (fMLP) stimulated oxidative burst (intracellular oxidation of dihydrorhodamine 123 to rhodamine ${ }_{123}$ ) were determined before, $\mathrm{l}$ h post, and $\mathrm{l}$ day post exercise. All cell counts were adjusted for changes in plasma volume using the formula of Dill and Costill. ${ }^{5}$

\section{NKCA}

NKCA was measured with NKTEST (Orpegen Pharma, Heidelberg, Germany) using fluorescently labelled K562 target cells. Heparinised blood $(5 \mathrm{ml})$ was diluted with phosphate buffered saline (PBS; 1:2) and layered onto $15 \mathrm{ml}$ Histopaque 1077 (Sigma, Deisenhofen, Germany). After centrifugation for $20 \mathrm{~min}$ at $700 \times g$, the mononuclear cell layer was resuspended in $12 \mathrm{ml}$ PBS, vortexed, and centrifuged $(10 \mathrm{~min}, 250 \times g)$. The supernatant was then aspirated, cells were resuspended in $1 \mathrm{ml}$ Complete Medium (Orpegen Pharma) and the cell concentration adjusted to $5 \times 10^{6}$ cells $/ \mathrm{ml}$. Rapidly thawed $\mathrm{K} 562$ target cells were suspended in $50 \mathrm{ml}$ prewarmed $\left(37^{\circ} \mathrm{C}\right)$ Complete Medium, vortexed, and centrifuged $(5 \mathrm{~min}, 120 \times \mathrm{g}$ ). The supernatant was aspirated, cells were resuspended in $1 \mathrm{ml}$ Complete Medium, and the cell concentration adjusted to $1 \times 10^{5} / \mathrm{ml}$. Effector cells were then mixed with K562 target cells at ratio of 50:1 and incubated in a final volume of $200 \mu \mathrm{l}$ of effector and target cell suspension and Complete Medium. In the high control samples $30 \mu \mathrm{l}$ interleukin-2 (IL-2) were added prior to the addition of the target cell suspension. In the negative control sample, no effector cells were added. All tubes were then centrifuged $(3 \mathrm{~min}, 120 \times \mathrm{g})$, incubated (120 min, humidified $\mathrm{CO}_{2}$ incubator), and placed on ice until flow cytometric analysis. To label permeabilised target cells, $50 \mu \mathrm{l}$ DNA Staining Solution (Orpegen Pharma) were added to each sample and incubated $\left(5 \mathrm{~min}, 0^{\circ} \mathrm{C}\right)$ after vortexing. Dead and live target cells were determined by flow cytometry (FACSScan), which was performed within $30 \mathrm{~min}$ after addition of DNA Staining Solution. Per cent specific lysis was determined by subtracting the percentage of dead cells in the control sample tube from the percentage of killed target cells in the test samples (normal sample and high control sample with IL-2), and the number of NK cells needed to lyse one target cell were then calculated (needed NK cells $=$ effector cells $\times \%$ NK cells measured by flow cytometry/target cells $\times \%$ specific lysis).

\section{Neutrophil and monocyte phagocytosis}

Neutrophil phagocytic activity was determined using a commercial test (PHAGOTEST; Orpegen Pharma), which allows the quantitative determination of fluorescein labelled opsonised Escherichia coli bacteria. Heparinised whole blood was vortexed and $100 \mu \mathrm{l}$ were aliquoted on the bottom of a $5 \mathrm{ml}$ tube and incubated in an ice bath for $10 \mathrm{~min}$. Afterwards, $20 \mu \mathrm{l}$ precooled $E$ coli bacteria were added and mixed. While the control samples remained on ice, the test samples were incubated for $10 \mathrm{~min}$ at $37^{\circ} \mathrm{C}$ in a water bath. After incubation, samples were put on ice and $100 \mu \mathrm{l}$ of ice cold Quenching Solution (Orpegen Pharma) and vortexed. Washing Solution ( $3 \mathrm{ml}$; Orpegen Pharma) was added and cells were spun down $\left(5 \mathrm{~min}, 250 \times \mathrm{g}, 4^{\circ} \mathrm{C}\right)$ twice and the supernatant discarded. After lysis for $20 \mathrm{~min}$ at room temperature with $2 \mathrm{ml}$ of prewarmed Lysing Solution (Orpegen Pharma), cells were spun down (5 min, $250 \times g$, $4^{\circ} \mathrm{C}$ ) and the supernatant discarded. After washing the samples with $3 \mathrm{ml}$ of Washing Solution and centrifugation $\left(5 \mathrm{~min}, 250 \times \mathrm{g}, 4^{\circ} \mathrm{C}\right), 200 \mu \mathrm{l}$ of DNA Staining Solution (Orpegen Pharma) were added, mixed, put on ice (light protected), and measured within $60 \mathrm{~min}$ by flow cytometry (FACSScan) collecting 10000 leukocytes per sample. After gating in the FSC versus SSC, percentages of neutrophils and monocytes having performed phagocytosis were analysed as well as their mean fluorescence intensity in the green fluorescence histogram, representing the number of ingested bacteria. The control sample was used to set a marker for fluorescence so that less than $1 \%$ of the events were positive.

\section{Neutrophil and monocyte oxidative burst}

As described by Rothe, ${ }^{6} 3 \mathrm{ml}$ heparinised peripheral blood ( $10 \mathrm{IU} / \mathrm{ml} \mathrm{Na}^{+}$heparin) were layered onto Histopack 1077

Table 1 Concentrations of metabolic parameters and hormones before and after exercise (Before ex, After ex) and corresponding values of the control day corresponding to the time point after exercise (After co-d)

\begin{tabular}{|c|c|c|c|c|c|c|c|c|}
\hline & $\begin{array}{l}\text { Lactate, } \\
\mathrm{mmol} / \mathrm{I}\end{array}$ & $\begin{array}{l}\text { Glucose, } \\
\mathrm{mmol} / \mathrm{l}\end{array}$ & $\begin{array}{l}\text { Triglycerides, } \\
\mathrm{mmol} / \mathrm{I}\end{array}$ & $\begin{array}{l}\mathrm{FFA}, \\
\mathrm{mmol} / \mathrm{I}\end{array}$ & $\begin{array}{l}\text { Glycerol, } \\
\mathrm{mmol} / \mathrm{I}\end{array}$ & $\begin{array}{l}\text { Epinephrine, } \\
\mathrm{nmol} / \mathrm{I}\end{array}$ & $\begin{array}{l}\text { Norepinephrine, } \\
\mathrm{nmol} / \mathrm{I}\end{array}$ & $\begin{array}{l}\text { Cortisol, } \\
\text { nmol//I }\end{array}$ \\
\hline Before ex & $1.7(0.4)$ & $6.4(1.1)$ & $1.57(0.66)$ & $0.15(0.05)$ & $0.06(0.03)$ & $0.55(0.05)$ & $2.4(0.1)$ & 604 (214) \\
\hline After ex & $1.5(0.5)^{*}$ & $4.4(0.7)^{*}$ & $1.33(0.27)^{*}$ & $1.71(0.60)^{*}$ & $0.41(0.10)^{*}$ & $0.87(0.13)^{*}$ & $4.6(1.3)^{*}$ & $\begin{array}{l}731(296)^{*} \\
503(244)+\end{array}$ \\
\hline & NS & $<0.001$ & NS & $<0.001$ & $<0.001$ & $<0.001$ & $<0.001$ & \\
\hline After co-d & - & - & $0.97(0.51)$ & $0.44(0.27)$ & $0.07(0.02)$ & - & - & $\begin{array}{l}362(113)^{*} \\
298(146)^{+}\end{array}$ \\
\hline $\mathrm{p}$ & - & - & $<0.05$ & $<0.001$ & $<0.001$ & - & - & $<0.001$ \\
\hline
\end{tabular}



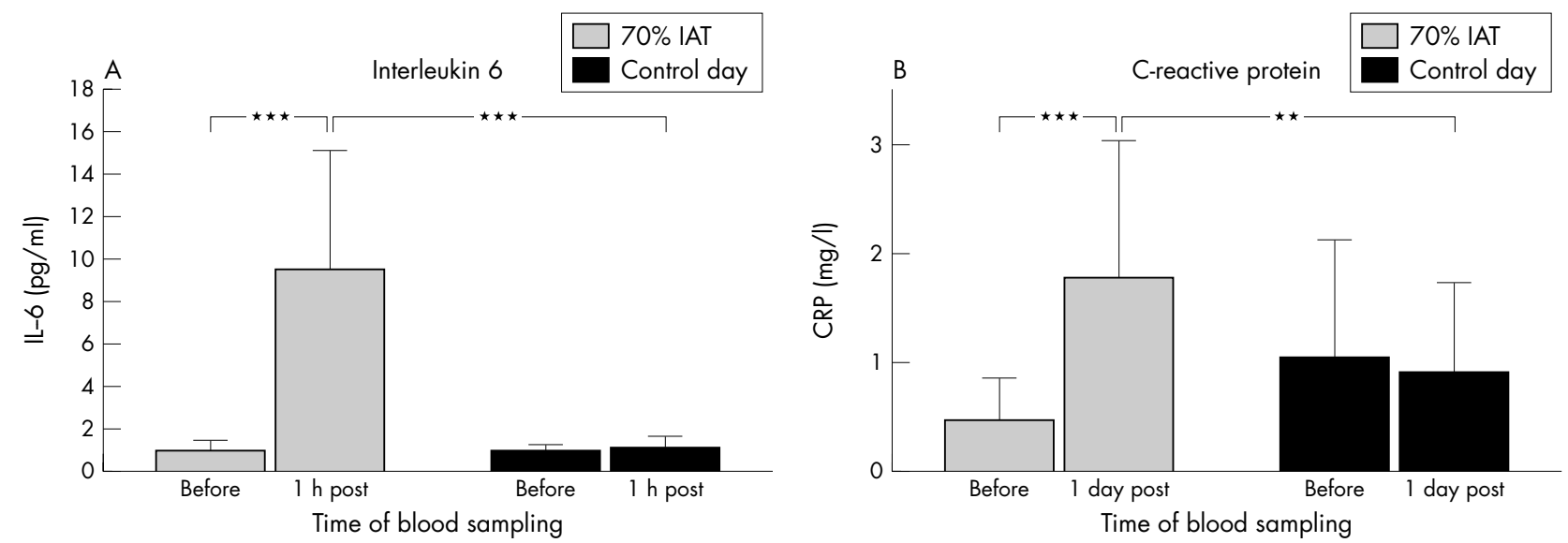

Figure 1 Concentrations of interleukin 6 and CRP before and after $4 \mathrm{~h}$ of cycling at an intensity of 70\% IAT. Interleukin 6 was determined $1 \mathrm{~h}$ after exercise ( $1 \mathrm{~h}$ post), CRP 1 day after exercise (1 day post). In addition, both parameters were determined on the control day without exercise at the corresponding time points.

(Sigma) to allow sedimentation of erythrocytes at room temperature without centrifugation within $50 \mathrm{~min}$. The leukocyte enriched supernatant was carefully harvested and put on ice. A volume of $1 \mathrm{ml}$ Hank's balanced salt solution (Sigma) containing $2 \times 10^{5}$ leucocytes was incubated at $37^{\circ} \mathrm{C}$ with $10 \mu \mathrm{l}$ dihydrorhodamine $(100 \mu \mathrm{ml} / \mathrm{l})$, and $10 \mu \mathrm{l}$ fMLP $(10 \mu \mathrm{mol} / \mathrm{l})$ were added after $5 \mathrm{~min}$. After $25 \mathrm{~min}$ of incubation samples were put on ice to stop the reaction and stained with propium iodide to differentiate living from dead cells. Flow cytometric measurements for gated neutrophils and monocytes, respectively, were made within 60 min after sample assessment.

\section{CRP, IL-6, metabolic parameters, and hormones}

CRP was determined turbidimetrically (Biomed, Oberschleißheim, Germany) and IL-6 by an enzyme linked immunoassay (R\&D Systems, Minneapolis, MN, USA). Lactate, glucose (Super GL, Greiner Biochemica), glycerol, and triglycerides were determined enzymatically (Vitalab 100S, Merck, Darmstadt, Germany), and free fatty acids by photometry (Photometer 1101M, Eppendorf, Germany). Cortisol was determined by chemoluminescence (Magic Lyte Analyzer, CIBA-Corning Diagnostics, Fernwald, Germany), and epinephrine and norepinephrine radioenzymatically.

\section{Statistics}

All data are presented as means (SD). Differences between the constant load trial and the control day were tested using a two factor analysis of variance (mode $\times$ time), and the
Newman-Keul's test was used for post hoc testing. Differences between pre- and post-exercise values for metabolic parameters and hormones were tested using a paired Student's $t$ test. Pearson's coefficient of correlation was used to test correlations between selected variables. An $\alpha$ error $<0.05$ was considered as significant.

\section{RESULTS}

\section{Metabolic parameters and hormones}

All 12 cyclists finished the constant load trial of $4 \mathrm{~h}$ duration without any problems. The mean power output was 181 (SD 23) $\mathrm{W}$, corresponding to a mean percentage of $72 \%$ (SD 5\%) of the maximal heart rate and to a mean percentage of $59 \%$ (SD 6\%) of the maximal oxygen consumption. Mean fluid consumption was 1.8 (SD 1) l mineral water. The results for metabolic parameters and hormones before and after exercise and the corresponding values of the control day are shown in table 1 .

\section{IL-6 and CRP}

Significant increases in IL-6 from 1.0 (SD 0.5) before to 9.6 (5.6) $\mathrm{pg} / \mathrm{ml} \mathrm{l} \mathrm{h}$ after exercise (fig lA) and in CRP from 0.5 (0.4) before to $1.8(1.3) \mathrm{mg} / \mathrm{l} \mathrm{l}$ day after exercise (fig $1 \mathrm{~B}$ ) were noted. Significant correlations between IL- 6 and the following parameters were found: CRP $(r=0.71, \mathrm{p}<0.01)$, epinephrine $(r=0.70, \mathrm{p}=0.01)$, norepinephrine $(r=0.63$, $\mathrm{p}=0.03)$, cortisol $(r=0.71, \mathrm{p}=0.01)$, and neutrophils $(r=0.74, \mathrm{p}=0.006)$. Furthermore, IL-6 correlated inversely to glucose $(r=-0.60, \mathrm{p}=0.04)$. IL-6 did not correlate to

Table 2 Leukocyte, neutrophil, monocyte, lymphocyte, and NK cell concentrations before and immediately, 1 h, 2 h, and 1 day (Before, End, $1 \mathrm{~h}$ post, $2 \mathrm{~h}$ post, 1 day post) after $4 \mathrm{~h}$ of cycling at an intensity of $70 \%$ IAT and at the corresponding time points on the control day without exercise

\begin{tabular}{|c|c|c|c|c|c|c|}
\hline Parameter & Mode & Before (SD) & End (SD) & $1 \mathrm{~h}$ post (SD) & $2 \mathrm{~h}$ post (SD) & 1 day post (SD) \\
\hline 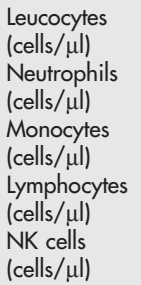 & $\begin{array}{l}70 \% \text { IAT } \\
\text { Control day } \\
70 \% \text { IAT } \\
\text { Control day } \\
70 \% \text { IAT } \\
\text { Control day } \\
70 \% \text { IAT } \\
\text { Control day } \\
70 \% \text { IAT } \\
\text { Control day }\end{array}$ & $\begin{array}{c}4958(1294) \\
5133(1061) \\
2949(1122) \\
3186(930) \\
393(155) \\
361(144) \\
1226(467) \\
1175(256) \\
167(81) \\
170(50)\end{array}$ & $\begin{array}{c}11186(3497) \\
5531(1193) \\
8716(2863) \\
3276(894) \\
507(161) \\
309(115) \\
1568(604) \\
1523(382) \\
294(133) \\
220(88)\end{array}$ & $\begin{array}{c}10609(3717) \\
5650(924) \\
8847(3483) \\
3450(701) \\
418(184) \\
364(73) \\
901(312) \\
1430(321) \\
57(28) \\
171(56)\end{array}$ & $\begin{array}{c}10746(3576) \\
6024(1228) \\
8389(3035) \\
3739(898) \\
513(185) \\
392(110) \\
1038(272) \\
1510(397) \\
103(55) \\
203(64)\end{array}$ & $\begin{array}{c}5479(1460) \\
5180(1215) \\
3340(1096) \\
3140(955) \\
382(177) \\
368(72) \\
1182(387) \\
1218(382) \\
157(72) \\
159(47)\end{array}$ \\
\hline
\end{tabular}

See text for statistics. 


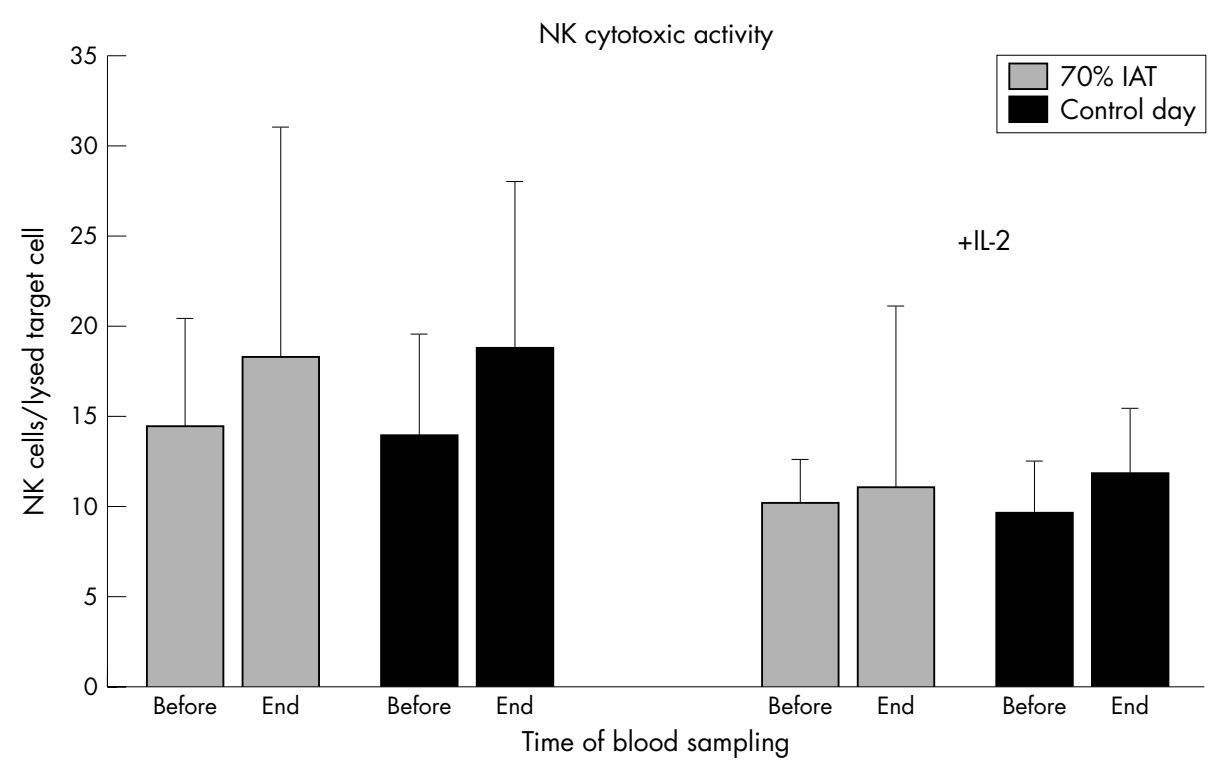

Figure 2 Unstimulated and interleukin 2 stimulated (+IL-2) NKCA on a per cell basis (shown as NK cells needed to lyse one K562 target cell) before (Before) and immediately after exercise (End) at an intensity of $70 \%$ as well as on the control day without exercise at the corresponding time points.

concentrations of free fatty acids, triglycerol, or glycerol or to activities of NK cells, neutrophils, or monocytes.

\section{Leukocyte and lymphocyte subpopulations}

Exercise induced changes of leukocytes, neutrophils, monocytes, lymphocytes, and NK cells are shown in table 2. Significant increases were found for leukocytes and neutrophils after cessation of (End), and 1 and $2 \mathrm{~h}$ after exercise ( $1 \mathrm{~h}$ post and $2 \mathrm{~h}$ post, respectively), which were $\sim 2$-fold for leukocytes and $\sim 3$-fold for neutrophils. The neutrophil count was significantly correlated to IL-6 $(r=0.74, \mathrm{p}=0.006)$ and, in trend, to cortisol $(r=0.54, \mathrm{p}=0.07)$. Furthermore, monocytes were significantly elevated after cessation of as well as $2 \mathrm{~h}$ after exercise.

Lymphocytes were raised significantly on both the exercise day and the control day at the time exercise ended but were diminished significantly at 1 and $2 \mathrm{~h}$ after exercise (table 2 ). Counts of NK cells were raised significantly after cessation of exercise but were significantly decreased at $\mathrm{l}$ and $2 \mathrm{~h}$ after exercise (table 2). The rise in NK cells was strongly correlated to epinephrine $(r=0.74, \mathrm{p}=0.005)$, and moderately to norepinephrine $(r=0.65, \mathrm{p}=0.02)$ and IL-6 $(r=0.61, \quad \mathrm{p}=0.04)$. Although $\mathrm{CD}^{-} \mathrm{CD}^{-} 6^{+} \mathrm{CD} 4^{+}$and $\mathrm{CD}^{-} \mathrm{CD}^{-} 6^{+} \mathrm{CD} 158 \mathrm{a}^{+}$lymphocytes were raised significantly at the end of exercise $(p<0.05)$, they had dropped to significantly under pre-exercise values at $\mathrm{l} \mathrm{h}$ and $2 \mathrm{~h}$ after exercise $(p<0.05)$ : CD94 $^{+}$lymphocytes/ $\mu \mathrm{l}: 102$ (SD 40) (before), 160 (77) (end), 30 (16) (1 h post), 50 (42) (2 h

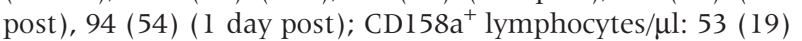
(before), 100 (44) (after), 19 (8) (1 h post), 31 (23) (2 h post), 45 (10) ( 1 day post). The mean fluorescence intensities of $\mathrm{CD}^{-} \mathrm{CD}^{-} 6^{+} \mathrm{CD} 94^{+}$and $\mathrm{CD} 3^{-} \mathrm{CD} 16^{+} \mathrm{CD} 158 \mathrm{a}^{+}$lymphocytes remained unchanged.

\section{NK cytotoxic activity (NKCA)}

The number of NK cells needed to lyse one K562 target cell did not significantly change. This was also true for the interleukin-2 stimulated NKCA (fig 2).

\section{Neutrophil and monocyte phagocytosis}

The relative number of phagocytising neutrophils and monocytes did not significantly change (neutrophils: 43\% (SD $10 \%$ ) (before), 39\% (9\%) (1 h post), and 42\% (12\%)
( 1 day post) on the exercise day $v 40 \%$ (10\%) (before), $41 \%$ ( $13 \%)$ ( 1 h post), and $45 \%$ ( $14 \%$ ) ( 1 day post) on the control day; monocytes: $25 \%$ (7\%) (before), $22 \%$ (5\%) ( 1 h post), and $26 \%(9 \%)$ ( 1 day post) on the exercise day $v 22 \%(10 \%)$ (before), 20\% (6\%) (1 h post), and 21\% (6\%) (1 day post) on the control day). The absolute number of phagocytising neutrophils was increased significantly after exercise, whereas the absolute number of phagocytising monocytes did not change (fig 3A and B). Mean fluorescence intensities of phagocytising neutrophils and monocytes did not change significantly.

\section{Neutrophil and monocyte oxidative burst}

The relative number of $\mathrm{Rh}_{123}{ }^{+}$neutrophils showed a significant different course between the exercise and the control days $(\mathrm{p}=0.04)$ with a significant increase from $\mathrm{l} \mathrm{h}$ post exercise to 1 day post exercise $(\mathrm{p}=0.04)$ : $33 \%$ (SD 15\%) (before), 27\% (15\%) (1 h post), and 35\% (14\%) (1 day post) on the exercise day $\vee 27 \%$ ( $11 \%$ ) (before), $28 \%$ (9\%) ( $1 \mathrm{~h}$ post), and $27 \%$ ( $7 \%$ ) ( 1 day post) on the control day. The absolute number of $\mathrm{Rh}_{123}{ }^{+}$neutrophils was significantly increased after exercise (fig 3C).

The relative numbers of $\mathrm{Rh}_{123}{ }^{+}$monocytes did not significantly change: $23 \%$ (SD 18\%) (before), $16 \%$ (11\%) ( 1 h post), and $20 \%$ (13\%) ( 1 day post) on the exercise day $v$ $19 \%(12 \%)$ (before), $19 \%$ (16\%) (1 h post), and $18 \%(10 \%)$ ( 1 day post) on the control day. The absolute number of $\mathrm{Rh}_{123}{ }^{+}$monocytes did not change (fig 3D). Although the mean fluorescence intensity of $\mathrm{Rh}_{123}{ }^{+}$monocytes did not show any significant changes, a significant effect of time for $\mathrm{Rh}_{123}{ }^{+}$neutrophils' mean fluorescence intensity was found $(\mathrm{p}=0.038)$, tending to decrease after exercise: 36 (SD 17) arbitrary units (AU) (before), 27 (9) AU (1 h post), and 33 (11) AU (1 day post) on the exercise day $v 34$ (19) AU (before), 34 (10) AU (1 h post), and 43 (24) AU (1 day post) on the control day.

\section{DISCUSSION}

The present study aimed to examine immunological reactions and immune cell function after prolonged exercise in well trained cyclists under standardised but realistic training conditions. Intensity was determined by means of the IAT to guarantee uniform individual strain in cyclists. ${ }^{89}$ An intensity 
of $70 \%$ IAT, which corresponded to $59 \% \mathrm{Vo}_{2 \max }$ in the present study, was chosen as cyclists usually spend about $80 \%$ of their training time below $65 \% \mathrm{Vo}_{2 \max } \cdot{ }^{3}$ Therefore, the present findings are representative for immune reactions in well trained and competitive cyclists during their training sessions.

\section{Acute phase response}

In the present study, a 3- to 4-fold increase in CRP and an almost 10-fold increase in IL-6 was observed, indicating a moderate acute phase response. This observation is in accordance with the results of previous studies which reported 3- to 10 -fold increases in CRP after exercise. ${ }^{1011}$ The increase in IL-6 is comparable to the increase after 2$2.5 \mathrm{~h}$ of cycle ergometric testing at $75 \% \mathrm{Vo}_{2 \max }$ reported recently, ${ }^{12}{ }^{13}$ is less than after competitive cycling $(250 \mathrm{~km}$ bicycle road race, duration $6.5 \mathrm{~h}),{ }^{14}$ and is higher than after a single maximal or repetitive anaerobic cycle ergometric test. ${ }^{15}$ The higher increases in IL-6 reported for runners (up to 100fold and more after a marathon race $)^{16-20}$ can be explained by the higher mechanical muscular strain.

According to previous reports, the increase in IL- 6 results from exercise induced decrease in blood glucose, as IL- 6 is produced in the contracting muscle ${ }^{21} 22$ to regulate substrate delivery and especially to maintain the glucose supply to glycogen depleted muscles. ${ }^{23}{ }^{24}$ Furthermore, the close relation between IL- 6 and CRP in the present study supports exercise induced release of CRP through hepatocytes, which is induced by IL- 6 . But in contrast to Pedersen and Keller, ${ }^{23}{ }^{25}$ we did not find a relation between the increase in IL- 6 and an increase in free fatty acids, glycerol, or triglycerides caused by the lipolytic effects of IL-6. Furthermore, although IL-6 has additional anti-inflammatory properties ${ }^{23}{ }^{24}$ and induces an increase in plasma cortisol, ${ }^{24}{ }^{26}{ }^{27}$ we did not find a relation to immune cell function.

\section{Exercise induced leukocytosis and immune cell function}

In a typical response to exercise, a more than 2-fold increase in the numbers of circulating leukocytes was observed, dominated by an almost 3 -fold increase in neutrophils which resulted from IL- 6 and cortisol mediated recruitment from the bone marrow as described previously. ${ }^{24} 2829$ Although lymphocytes were not elevated significantly at the end of exercise, a significant increase in NK cells was noted. This increase is thought to be induced by the catecholamine mediated down regulation of adhesion molecules. ${ }^{30}$ The post exercise reductions observed in lymphocytes and NK cells, however, were negatively correlated with both epinephrine and IL-6 mediated increases in cortisol and were in accordance with previous reports. ${ }^{23} 31$

But beyond alterations in absolute cell numbers, an attenuated immune function of different leukocyte subsets has been discussed in the literature, ${ }^{32-38}$ which might be responsible for greater susceptibility to opportunistic infections within the first hours after exercise and therefore are termed the "open window". ${ }^{1}$ As NK cells and macrophages represent the first line of defence, they have attracted particular interest.

\section{NK cell activity (NKCA)}

No differences in single cell NKCA were observed between before and after exercise, nor between the day of exercise and the control day. This was also true for the in vitro IL-2
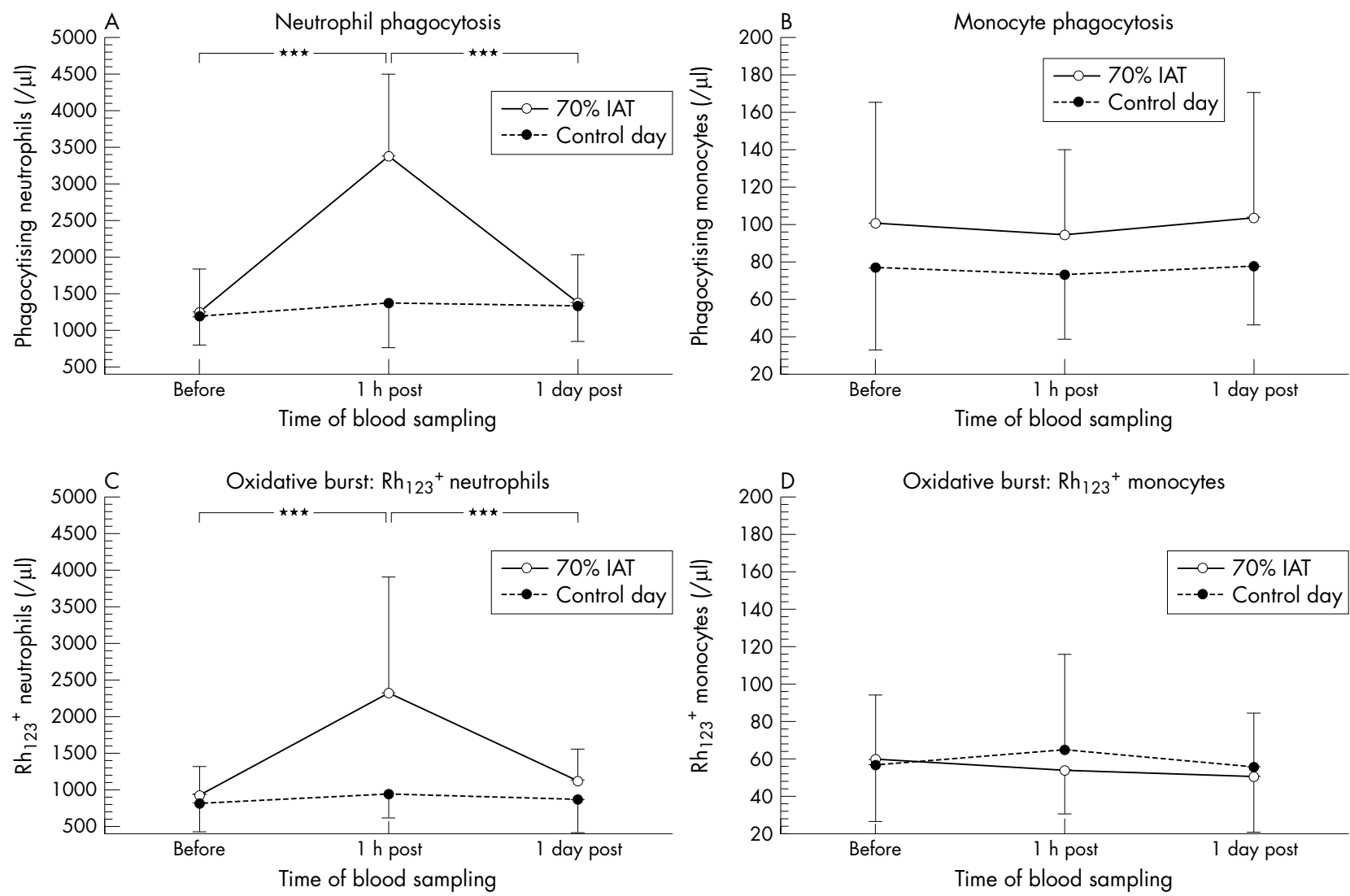

Figure 3 Absolute numbers of phagocytising neutrophils and monocytes ( $\mathrm{A}$ and $\mathrm{B}$ ) and absolute numbers of $\mathrm{Rh}_{123^{+}}$neutrophils and $\mathrm{Rh}_{123}{ }^{+}$monocytes ( $C$ and D) before (Before), $1 \mathrm{~h}$ and 1 day after ( $1 \mathrm{~h}$ post, 1 day post) $4 \mathrm{~h}$ of cycling at an intensity of $70 \%$ IAT as well as on the control day without exercise at the corresponding time points. 
stimulated single cell NKCA, which, given that exercise increases the level of activity in part through IL-2 by an enhanced IL-2 receptor expression on NK cells, could have been more sensitive. Also the unchanged mean fluorescence intensities of $\mathrm{CD}^{-}{ }^{-} \mathrm{CD} 16^{+} \mathrm{CD}_{9} 4^{+}$and $\mathrm{CD}^{-} \mathrm{CD} 16^{+} \mathrm{CD} 158^{+}$ lymphocytes suggest that exercise had no influence on the expression levels on CD94 or CD158a receptors, which either activate or inhibit NK cell function. ${ }^{39}$ Taken together, single cell NKCA was unaffected.

The present observations accord well with previous reports on single cell NKCA using $\mathrm{Cr}^{51}$ labelled K562 target cells. ${ }^{40}$ Nevertheless, they must be differentiated from an intensity dependent increase in total NKCA (reflecting the overall cytotoxic activity of a given population of peripheral blood mononuclear cells with an exercise induced higher proportion of NK cells) during or immediately after exercise. ${ }^{40} \mathrm{NK}$ cell function expressed on a per cell basis has been reported to remain unchanged immediately after exercise in runners after $45 \mathrm{~min}$ to $2.5 \mathrm{~h}$ of treadmill running at intensities ranging from 50 to $85 \% \mathrm{Vo}_{2 \max }{ }^{41-43}$ or after repeated cycle ergometric testing. ${ }^{44}$ Therefore, these previous findings can be extended to even longer exercise bouts by the present results. As single cell NKCA may not be affected even by prolonged exercise, it seems that augmented or attenuated immunocompetence of NK cells is more a matter of numerical redistribution than of single cell NKCA.

\section{Neutrophil and monocyte phagocytosis and oxidative burst}

Although exercise induced an increase in absolute numbers of phagocytising neutrophils (but not in monocytes), neither neutrophil nor monocyte phagocytosis on a per cell basis was affected by prolonged cycling in the present study. This finding is in accordance with the results of Malpica et a $l^{45}$ who did not find an effect of exercise on the functional capacity of neutrophils due to small variations of epinephrine, whereas high concentrations of epinephrine, high intensity exercise, and exercise to exhaustion seem to alter neutrophil phagocytic capacity. ${ }^{32}{ }^{45-47}$ Therefore, a typical cycling training session does not seem to alter the phagocytic capacity of monocytes or neutrophils.

Nevertheless, other mechanisms of microbial killing may be suppressed before the phagocytic capacity of macrophages is reduced. In the present study, neutrophil oxidative burst may have been more affected than other tested activities. Representing a semiquantitative estimate of the intracellular production of reactive oxygen intermediates per cell, ${ }^{48}$ the mean fluorescence intensity of $\mathrm{Rh}_{123}{ }^{+}$neutrophils showed a significant effect over time and tended to be somewhat lower after exercise than before or the day after. This temporary affection presumably resulted from the IL-6 and cortisol induced increased influx of less mature neutrophils into the circulation from the bone marrow and the marginal pool as well as from direct cortisol effects on intracellular glucocorticoid binding sites. However, whether this small effect contributes to a higher susceptibility to infection in endurance athletes and therefore supports the open window theory remains unclear and needs further investigation. Taken together, although a minor temporary effect of neutrophil oxidative burst was found in the present study, the function of macrophages does not seem to be altered seriously within the first hours after prolonged cycling at moderate intensities.

\section{CONCLUSION}

Prolonged cycling at moderate intensities induces a moderate acute phase response and possibly induces a moderate affection of neutrophil oxidative burst, whereas neutrophil and monocyte phagocytosis as well as NK cell activity remain unaffected. In conclusion, prolonged cycling at moderate
What is already known on this topic

Prolonged exercise may induce temporary immunosuppression with a presumed increased susceptibility for infection. However, little is known about immune cell function after prolonged cycling at moderate intensities.

\section{What this study adds}

Although prolonged exercise may induce temporary immunosuppression, a single typical road cycling training session appears to be safe from an immunological point of view.

intensities does not seem to seriously alter the function of cells in the first line of defence. Therefore, the influence of a single typical road cycling training session on the immune system is only moderate and appears to be safe from an immunological point of view.

\section{Authors' affiliations}

J Scharhag, T Meyer, B Schlick, O Faude, W Kindermann, Institute of Sports and Preventive Medicine, University of Saarland, Saarbrücken, Germany

H H W Gabriel, Department of Sports Medicine, Friedrich-SchillerUniversity, Jena, Germany

This study was supported by a grant from the National Institute for Sports Sciences (Bundesinstitut für Sportwissenschaft, VF 0407/01/11/992000), Bonn, Germany

Competing interests: none declared

\section{REFERENCES}

1 Pedersen BK, Ullum H. NK cell response to physical activity: possible mechanisms of action. Med Sci Sports Exerc 1994;26:140-6.

2 Nieman DC. Nutrition, exercise, and immune system function. Clin Sports Med 1999; 18:537-48.

3 Lucia A, Hoyos J, Chicharro J. Physiology of professional road cycling. Sports Med 2001;31:325-7.

4 Stegmann H, Kindermann W, Schnabel A. Lactate kinetics and individual anaerobic threshold. Int J Sports Med $1981 ; 2: 160-5$.

5 Dill DB, Costill DL. Calculation of percentage changes in volume of blood, plasma, and red cells in dehydration. J Appl Physiol 1974;37:247-8

6 Rothe G, Kellermann W, Schaerer B, et al. Messung der phagosomalen Wasserstoffperoxidproduktion von Granulozyten und Monozyten mit Dihydrorhodamin 123. In: Schmitz G, Rothe G, eds. Durchflußzytometrie in der klinischen Zelldiagnostik. Stuttgart: Schattauer, 1994:331-50.

7 Da Prada M, Zürcher G. Simultaneous radioenzymatic determination of plasma and tissue adrenaline, noradrenaline and dopamine within the femtomole range. Life Sci 1976;19:1 161-74.

8 Meyer T, Gabriel H, Kindermann W. Is determination of exercise intensities as percentages of VO2max or HRmax adequate? Med Sci Sports Exerc 1999;31:1342-5.

9 Meyer T, Faude O, Gabriel $\mathrm{H}$, et al. Ventilatory threshold and individual anaerobic threshold are reliable prescriptors for intensity of cycling training Med Sci Sports Exerc 2000;32(suppl 5):S171.

10 Cannon J. Exercise and the acute phase response. In: Hoffmann-Goetz L, eds. Exercise and immune function. Boca Raton, FL: CRC Press, 1996:39-54.

11 Taylor C, Rogers G, Goodman C, et al. Hematologic, iron-related, and acutephase protein responses to sustained strenuous exercise. J Appl Physiol 1987;62:464-9.

12 Hiscock N, Petersen E, Krzywkowski K, et al. Glutamine supplementation further enhances exercise-induced plasma IL-6. J Appl Physiol 2003;95:145-8.

13 Nieman DC, Nehlsen-Cannarella S, Fagoaga O, et al. Influence of mode and carbohydrate on the cytokine response to heavy exertion. Med Sci Sports Exerc 1998;30:671-8

14 Gannon G, Rhind S, Suzui M, et al. Circulating levels of peripheral blood leucocytes and cytokines following competitive cycling. Can J Appl Physiol 1997;22:133-47.

15 Meyer T, Gabriel H, Rätz M, et al. Anaerobic exercise induces moderate acute phase response. Med Sci Sports Exerc 2001;33:549-55.

16 Castell L, Poortmans J, Leclercq R, et al. Some aspects of the acute phase response after a marathon race, and the effects of glutamine supplementation. Eur J Appl Physiol Occup Physiol 1997;75:47-53. 
17 Ostrowski K, Rohde T, Asp S, et al. Pro- and anti-inflammatory cytokine balance in strenuous exercise in humans. J Physiol 1999;515:287-91.

18 Starkie R, Rolland J, Angus D, et al. Circulating monocytes are not the source of elevations in plasma IL-6 and TNF-alpha levels after prolonged running. Am J Physiol Cell Physiol 2001;280:C769-74.

19 Suzuki K, Nakaji S, Yamada M, et al. Systemic inflammatory response to exhaustive exercise. Cytokine kinetics. Exerc Immunol Rev 2002;8:6-48.

20 Suzuki K, Nakaji S, Yamada M, et al. Impact of a competitive marathon race on systemic cytokine and neutrophil responses. Med Sci Sports Exerc 2003;35:348-55.

21 Moldoveanu A, Shephard R, Shek P. Exercise elevates plasma levels but not gene expression of IL-1 beta, IL-6, and TNF-alpha in blood mononuclear cells. J Appl Physiol 2000;89:1499-504.

22 Steensberg A, van Hall G Osada T, et al. Production of interleukin-6 in contracting human skeletal muscles can account for the exercise-induced increase in plasma interleukin-6. J Physiol 2000;529:237-42.

23 Pedersen B, Steensberg A, Keller P, et al. Muscle-derived interleukin-6: lipolytic, anti-inflammatory and immune regulatory effects. Pflugers Arch 2003:446:9-16.

24 Steensberg A, Fischer C, Keller C, et al. IL-6 enhances plasma IL-1 ra, IL-10, and cortisol in humans. Am J Physiol Endocrinol Metab 2003;285:E433-7.

25 Keller C, Keller P, Marshal S, Pedersen B. IL-6 gene expression in human adipose tissue in response to exercise - effect of carbohydrate ingestion. J Physiol 2003;550:927-31.

26 Febbraio M, Steensberg A, Keller C, et al. Glucose ingestion attenuates interleukin-6 release from contracting skeletal muscle in humans. J Physio 2003:549:607-12.

27 Nieman DC, Davis JM, Henson DA, et al. Carbohydrate ingestion influences skeletal muscle cytokine mRNA and plasma cytokine levels after a 3-h run. J Appl Physiol 2003;94:1917-25.

28 Peake J. Exercise-induced alterations in neutrophil degranulation and respiratory burst activity: possible mechanisms of action. Exerc Immunol Rev 2002;8:49-100.

29 Suwa T, Hogg J, English D, et al. Interleukin-6 induces demargination of intravascular neutrophils and shortens their transit in marrow. Am J Physiol Heart Circ Physiol 2000;279:H2954-60.

30 Nagao F, Suzui M, Takeda K, et al. Mobilization of NK cells by exercise: downmodulation of adhesion molecules on NK cells by catecholamines. Am J Physiol Regul Integr Comp Physiol 2000;279:R1 251-6.

31 Steensberg A, Toft A, Bruunsgaard $\mathrm{H}$, et al. Strenuous exercise decreases the percentage of type $1 \mathrm{~T}$ cells in the circulation. J Appl Physiol 2001:91:1708-12.

32 Gabriel H, Muller H, Kettler K, et al. Increased phagocytic capacity of the blood, but decreased phagocytic activity per individual circulating neutrophil after an ultradistance run. Eur J Appl Physiol Occup Physiol 1995;71:281-4.

33 Nieman DC, Nehlsen-Cannarella S, Fagoaga O, et al. Effects of mode and carbohydrate on the granulocyte and monocyte response to intensive, prolonged exercise. J Appl Physiol 1998;84:1252-9.

34 Nehlsen-Cannarella SL, Fagoaga OR, Nieman DC, et al. Carbohydrate and the cytokine response to $2.5 \mathrm{~h}$ of running. J Appl Physiol 1997:82:1662-7.

35 Pedersen BK, Tvede N, Hansen F, et al. Modulation of natural killer cell activity in peripheral blood by physical exercise. Scand J Immunol 1988;27:637-8.

36 Pedersen BK, Tvede N, Klarlund K, et al. Indomethacin in vitro and in vivo abolishes post-exercise suppression of natural killer cell activity in peripheral blood. Int J Sports Med 1990;11:127-31.

37 Pyne D, Baker M, Smith J, et al. Exercise and the neutrophil oxidative burst: biological and experimental variability. Eur J Appl Physiol 1996;74:564-71.

38 Scharhag J, Meyer T, Gabriel H, et al. Mobilization and oxidative burst of neutrophils are influenced by carbohydrate supplementation during prolonged cycling in humans. Eur J Appl Physiol 2002;87:584-7.

39 Middleton D, Curran M, Maxwell L. Natural killer cells and their receptors. Transpl Immunol 2002;10:147-64.

40 Rowbottom D, Green K. Acute exercise effects on the immune system. Med Sci Sports Exerc 2000;32:S396-405.

41 Miles M, Mackinnon L, Grove D, et al. The relationship of natural killer cell counts, perforin mRNA and CD2 expression to post-exercise natural killer cell activity in humans. Acta Physiol Scand 2002;174:317-25.

42 Nieman DC, Ahle JC, Henson DA, et al. Indomethacin does not alter natural killer cell response to $2.5 \mathrm{~h}$ of running. J Appl Physiol 1995;79:748-55.
43 Nieman DC, Miller A, Henson DA, et al. Effects of high- vs moderate-intensity exercise on natural killer cell activity. Med Sci Sports Exerc 1993;25: 11 126-34.

44 McFarlin B, Mitchell J, McFarlin M, et al. Repeated endurance exercise affects leukocyte number but not NK cell activity. Med Sci Sports Exerc 2003;35:1130-8

45 Malpica M, Rodriguez A, Saez M, et al. In-vitro study of the effect of adrenaline on the functional capacity of human neutrophils: role during exercise. J Neuroendocrinol 2002;14:824-8.

46 Ferrandez M, De la Fuente M. Effects of age, sex and physical exercise on the phagocytic process of murine peritoneal macrophages. Acta Physiol Scand 1999; 166:47-53.

47 Krause R, Patruta S, Daxbock F, et al. Effect of vitamin C on neutrophil function after high-intensity exercise. Eur J Clin Invest 2001;31:258-63

48 Gabriel H, Müller HJ, Urhausen A, et al. Suppressed PMA-induced oxidative burst and unimpaired phagocytosis of circulating granulocytes one week after a long endurance exercise. Int J Sports Med 1994;15:441-5.

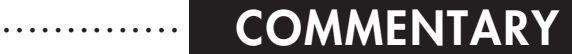

Over the past 15 years, several authors have argued that a temporary depression in the immune response associated with a prolonged bout of intensive exercise may be sufficient to reduce the immediate defences of the body against viral infection, with a resultant increase in the incidence of upper respiratory infections. ${ }^{1}$ The present paper looks at the changes in various immune parameters seen when a small group of distance cyclists and triathletes cycle for $4 \mathrm{~h}$ at some $59 \%$ of their peak oxygen intake $(70 \%$ of their individual anaerobic threshold). Findings are compared with data for the same individuals tested on a control day. The observed changes in immune function are small, and it is thus argued that distance training is safe from an immunological point of view. The crucial question is whether the exercise intensity chosen for the present experiments is representative of that adopted by athletes when they are undertaking serious training. The limited increases in epinephrine and norepinephrine concentrations show that subjects did not find the chosen protocol particularly stressful, and one might question whether many competitors would not train much closer to the intensity adopted during a road race (which can be as high as $95 \%$ rather than $70 \%$ of the ventilatory threshold for an event of 6-7 h duration ${ }^{2}$ ). Nevertheless, amateur participants in marathon events may well train at only $70 \%$ of their anaerobic threshold, and assuming that one can apply the present findings to the response of low level performers, then the latter group seem unlikely to harm their immune systems during moderate training sessions.

R J Shephard

PO Box 521, 41390 Dryden Road, Brackendale, Canada VON 1HO; royjshep@shaw.ca

\section{REFERENCES}

1 Shephard RJ. Overview of the epidemiology of exercise immunology. Immunol Cell Biol 2000;78:485-95.

2 Gannon GA, Rhind SG, Suzui M, et al. Circulating levels of peripheral blood leukocytes and cytokines following competitive cycling. Can J Appl Physiol 1997;22:133-47. 